\title{
Freedom of Speech in the Public Workplace: A Comment on the Public Concern Requirement
}

\author{
Cynthia K. Y. Lee†
}

\section{INTRODUCTION}

The principle of the freedom of speech springs from the necessities of the program of self-government. It is not a Law of Nature or of Reason in the abstract. It is a deduction from the basic American agreement that public issues shall be decided by universal suffrage. ${ }^{1}$

$$
\text { -A. Meiklejohn }
$$

Speech on public issues traditionally has occupied the "highest rung of the hierarchy of First Amendment values."2 Protecting the right of all citizens to speak on matters of public concern is a primary interest underlying the first amendment. ${ }^{3}$ In cases involving public employees, however, the courts consider not only the employee's right as a citizen to present issues of political and social concern to the community, but also

$\dagger$ B.A. 1983, Stanford University; third-year student, Boalt Hall School of Law, University of California, Berkeley. The author would like to thank Professor Robert Post, Ellen Kaulbach, and Karen Kennard for their guidance and assistance in preparing this Comment for publication.

1. A. Meiklejohn, Political Freedom 27 (1960).

2. NAACP v. Claiborne Hardware Co., 458 U.S. 886, 913 (1982).

3. Although a discussion of all underlying first amendment interests is beyond the scope of this Comment, the views of several Supreme Court Justices and scholars are particularly noteworthy.

Justice Holmes, in his famous dissenting opinion in Abrams v. United States, identified "free trade in ideas" as an important interest underlying the first amendment:

But when men have realized that time has upset many fighting faiths, they may come to believe even more than they beheve the very foundations of their own conduct that the ultimate good desired is better reached by free trade in ideas-that the best test of truth is the power of thought to get itself accepted in the competition of the market, and that truth is the only ground upon which their wishes safely can be carried out.

250 U.S. 616, 630 (1919) (Holmes, J., dissenting).

Martin H. Redish argues that "the constitutional guarantee of free speech ultimately serves only one true value, ... " individual self-realization." " Redish, The Value of Free Speech, 130 U. PA. L. REV. 591, 593 (1982).

Geoffrey R. Stone suggests that the concept of equality underlies the first amendment. Specifically, he has written that "[w]hen government restricts only certain ideas, viewpoints, or items of information, people wishing to express the restricted messages receive 'unequal' treatnient." Stone, Content Regulation and the First Amendment, 25 WM. \& MARY L. REV. 189, 202 (1983).

Vincent Blasi argues that a recognition of "the value that free speech . . . can serve in checking the abuse of power by public officials" underlies the Supreme Court's decision in New York Times Co. v. Sullivan, 376 U.S. 254 (1964). Blasi, The Checking Value in First Amendment Theory, 1977 AM. B. Found. RES. J. 521, 527. 
the government's interest as an employer in guaranteeing the smooth operation of the workplace. ${ }^{4}$ Particularly when a public employee is disciplined $^{5}$ for criticizing the operation of the government office in which she works, the judiciary may be called upon to balance the employee's interest in free speech against the government employer's interest in managing the workplace.

To address these conflicting interests, the United States Supreme Court developed a two-part test known as the Pickering test. ${ }^{6}$ Under this test, the court's threshold inquiry is whether the employee's speech may be "fairly characterized as constituting speech on a matter of public concern."7 Only when a court finds the speech of public concern will it balance the pubhe employee's interest in free expression against the interests of the government employer in managing the workplace. ${ }^{8}$ If the public employee's speech does not pass the public concern requirement, it is not constitutionally protected under the first amendment, and the court will not review the disciphinary action.

In the twenty years since adopting the Pickering test, the Court has done little to clarify what types of public employee speech are constitutionally protected or, more specifically, what constitutes a matter of public concern. ${ }^{9}$ This problem surfaced recently in Rankin v. McPherson, ${ }^{10}$ a 5-4 Supreme Court decision, in which the majority concluded that the employee's speech "plainly dealt with a matter of public concern," 11 and the dissent concluded just as strongly that it was not a inatter of public concern. ${ }^{12}$

The Pickering Court stated that it did not more clearly delineate its test because a rigid rule would not accommodate the myriad of possible fact situations that might arise in a public employee speech case. ${ }^{13}$ Yet,

4. Pickering v. Board of Educ., 391 U.S. 563, 568 (1968).

5. For purposes of this Comment, government disciplinary action may include dismissal, discharge, and any other adverse personnel action taken against a public employee for speech related activity.

6. See Pickering v. Board of Educ., 391 U.S. 563 (1968).

7. Rankin v. McPherson, 107 S. Ct. 2891, 2897 (1987) (quoting Connick v. Myers, 461 U.S. 138, 146 (1983)).

8. Id. at 2898 .

9. The Ninth Circuit has noted, "[ $t$ ]he Court has not articulated a precise definition of "public concern,' however. It has allowed only that the determination of whether an employee's speech deals with such an issue is to be made with reference to the 'content, form, and context' of the speech." Allen v. Scribner, 812 F.2d 426, 430 (quoting Connick v. Myers, 461 U.S. 138, 147-48 (1983)), modified, 828 F.2d 1445 (9th Cir. 1987).

10. 107 S. Ct. 2891 (1987).

11. Id. at 2897.

12. Id. at 2902 (Scalia, J., dissenting).

13. The Court explained that

[b]ecause of the enormous variety of fact situations in which critieal statements by teachers and other public employees may be thought by their superiors, against whom the statements are directed, to furnish grounds for dismissal, we do not deem it either 
partly because the parameters of public concern are unclear, the public concern requirement insufficiently addresses the concerns which led the Supreme Court to create a threshold test: disruption of the workplace caused by the speech itself and impairment of managerial authority caused by judicial review.

This Comment focuses on the first prong of the Pickering test, discussing the rationale behind the public concern requirement and the problems this test has created. Part I presents the historical background of public employee free speech rights. Part II first discusses the various concerns that the Court sought to address by instituting the public concern requirement, then examines whether the public concern test adequately addresses these concerns. Part III introduces a theoretical framework for understanding judicial review of public employee speech and discusses the advantages and shortcomings of two different levels of review-independent review and deference.

Part IV presents a reformulation of the Pickering test to better reflect the Supreme Court's decisions in the area of free speech in the public workplace. The reformulation replaces the current threshold inquiry with a test that focuses on whether the speech clearly impaired the government institution's ability to function. If the public employee's speech does not clearly impair the institution's ability to function, it is constitutionally protected. The court must then decide whether to independently review the reasons for the adverse personnel decision or defer to the government employer's decision that the speech was disruptive.

This Comment suggests that the determination whether to review or defer turns on the role of the employee. Recent Supreine Court decisions disclose that the Court currently considers three factors relevant to this question under a "totality of the circumstances" test: (1) whether the speech took place at the workplace; (2) whether the speech was related to the employment; and (3) whether the speech was of public concern. If, on the whole, the employee was speaking more as an employee than as a citizen, the court defers. If the employee spoke more as a citizen than as an employee, then the court independently reviews. In light of the value of free speech in general, and the importance of protecting freedom of expression for public employees in particular, this Coinment recommends that courts independently review the adverse personnel decision whenever any of these three factors indicate that the employee spoke in his capacity as a citizen.

appropriate or feasible to attempt to lay down a general standard against which all such statements may be juoged.

Pickering v. Board of Educ., 391 U.S. 563, 569 (1968). 


\section{HistoricAl BACKgROUND}

The evolution of public employee free speech rights has undergone three distinct phases. In the first phase, which lasted until the early 1950s, the Supreme Court consistently upheld public employee disciplinary actions-even when such dismissals threatened fundamental constitutional rights-on the theory that government employment was a privilege, not a right. ${ }^{14}$ During the second phase, which lasted from the early 1950 s to the late 1960 s, the Court began to recognize that public employees do not necessarily rehinquish their constitutional rights by accepting employment with the government. ${ }^{15}$ Although the Court contimued to favor the government in public employee constitutional rights cases, it was clear by the late 1960 s that the Court had rejected its earlier view that government employees give up their constitutional rights by accepting government employment. ${ }^{16}$ In the third and current phase, the Court established the two-part Pickering test as the standard for deciding public employee speech cases. Since Pickering, however, the Court has fluctuated between deference to the state as an employer ${ }^{17}$ and recognition of the public employee's right to speak on public issues. ${ }^{18}$

\section{A. The Right-Privilege Distinction}

Originally, the Supreme Court treated the government like a private einployer with respect to its ability to discharge its employees. ${ }^{19}$ In the private sector, an employer can generally discharge an employee without notice or cause unless the employment contract specifies otherwise. ${ }^{20}$ Prior to the 1950s, a government employer, like its private sector counterpart, could dismiss its employees at will, ${ }^{21}$ even if the employer based

14. See Note, Public Employees and the First Amendment: Connick v. Myers, 15 LoY. U. CHI. L.J. 293, 295 (1984) (authored by Christine M. Arden).

15. Id. at 295-96.

16. See Note, The First Amendment and Public Employees - An Emerging Constitutional Right To Be A Policeman?, 37 Geo. WASH. L. REv. 409, 411-12 (1968)(authored by Henry V. Nickel).

17. See, e.g., Connick v. Myers, 461 U.S. 138, 151-82 (1983) ("When close working relationships are essential to fulfilling public responsibilities, a wide degree of deference to the employer's judgment is appropriate.").

18. See, e.g., Rankin v. McPherson, 107 S. Ct. 2891, 2900 (1987) ("Given the function of the agency, McPherson's position in the office, and the nature of her statement, we are not persuaded that Rankin's interest in discharging her outweighed her rights under the First Amendment.").

19. Note, The First Amendment and Public Employees: Times Marches On, 57 GEo. L.J. 134, 135 (1968) (state likened to a private employer with regard to discharge of employees).

20. Feinman, The Development of the Employment at Will Rule, 20 AM. J. LEGAL HisT. 118, 118 (1976); see also 3A A. Corbin, CoRbin on Contracts $\S 684$, at 224 (1960).

21. Under employment at will, the employer can terminate the employment relationship without notice and without cause. Feinman, supra note 20. 
the discharge on the employee's exercise of first amendment rights. ${ }^{22}$ The Court's rationale for upholding such dismissals was that since a public einployee had no constitutional right to government employment, the state could prescribe the terms of such employment even if these terms infringed on otherwise constitutionally protected rights. ${ }^{23}$ The distinction between constitutionally protected rights of private citizens and the unprotected privilege of public employment was termed the riglit-privilege distinction. ${ }^{24}$

The Court's 1952 decision, Adler v. Board of Education, ${ }^{25}$ exemplifies its traditional posture of upholding government employee dismissals even when such dismissals called constitutional rights into question. In Adler, the Court upleld New York civil service laws that prohibited teachers from belonging to organizations that advocated the overthrow of the Umited States government. The Court reasoned that since public employment was a privilege, it could be conditioned upon the surrender of constitutional rights: ${ }^{26}$

It is clear that [employees or persons seeking employment in the public schools of New York] have the right under our law to assemble, speak, think and believe as they will. It is equally clear that they have no right to work for the State in the school system on their own terms. They may work for the school system upon the reasonable terms laid down by the proper authorities of New York. If they do not choose to work on such terms, they are at liberty to retain their behiefs and associations and go elsewhere. ${ }^{27}$

The Adler Court analogized public employment to at-will employment in the private sector. ${ }^{28}$ The Court asserted that "for constitutional purposes, the 'government as employer' is more like a private employer than like a government." 29 Since private employers could fire employees for any reason or no reason at all, so could the government, even if suclr

22. Note, supra note 19 , at 135.

23. This doctrine is capsulated by the oft-quoted dictum of Mr. Justice Holmes: "The petitioner may have a constitutional right to talk politics, but he has no constitutional right to be a policeman." McAuliffe v. Mayor of New Bedford, 155 Mass. 216, 220, 29 N.E. 517, 517 (1892). See generally Van Alstyne, The Demise of the Right-Privilege Distinction in Constitutional Law, 81 HARV. L. REV. 1439 (1968) (arguing that the concept of privilege is no longer viable and that substantive due process control should be exerted).

24. Van Alstyne, supra note 23, at 1140-42.

25. 342 U.S. 485 (1952), overruled in part, Keyishian v. Board of Regents, 385 U.S. 589, 595 (1967) (Adler overruled to the extent that it upheld law disqualifying persons from employment in public schools).

26. Id. at 492; see also Keyishian v. Board of Regents, 385 U.S. 589, 605-06 (1967) (invalidating the New York civil service laws upheld in Adler).

27. Adler, 342 U.S. at 492 (citations omitted).

28. Note, Developments in the Law: Public Employment, 97 HARV. L. REv. 1611, 1743 (1984).

29. Id. 
discharge trampled on the fundamental constitutional rights of its employees.

\section{B. Evolution of the Unconstitutional Conditions Doctrine}

In the 1950s, the Court began to retreat from its position that the government as an employer could fire its employees for activities normally protected by the Constitution. Just nine months after Adler, in Wieman v. Updegraff,,$^{30}$ the Court held invalid an Oklahoma statute that required state employees to take a "loyalty oath" denying affiliation with "subversive" organizations. The Court held that this statute violated the due process clause of the fourteenth amendment. To explain its apparent deviation from Adler, the Weiman Court stated, "To draw from [Adler] the facile generalization that there is no constitutionally protected right to public employment is to obscure the issue. . . . It is sufficient to say that constitutional protection does extend to the public servant ...."31

The Court's initial recognition of public eniployees' constitutional rights in Weiman did not lead immediately to a rash of decisions in favor of the employee. ${ }^{32}$ Throughout the 1950s, the Court recognized only one public employee's claim that his dismissal was invalid on constitutional grounds, ${ }^{33}$ and rejected all other constitutional challenges to such dismissals. ${ }^{34}$

By the 1960s, however, the Court no longer accepted the argunient that the government as an eniployer had virtually unlimited power to place restrictions upon the privilege of governnient employment. ${ }^{35}$ This change in position was reflected in Sherbert v. Verner. ${ }^{36}$ In Sherbert, the Court held unconstitutional a South Carolina statute which denied unemployment compensation to individuals who refused to work at certain times, as applied to a Seventh Day Adventist whose religious beliefs prohibited her from working on Saturdays. The Court reasoned that the government could not impair an individual's constitutional rights by placing conditions on the receipt of a government benefit or privilege:

30. 344 U.S. 183 (1952).

31. Id. at 191-92.

32. Note, supra note 16 , at 411 .

33. Slochower v. Board of Higher Educ., 350 U.S. 551 (1956) (dismissal of city college teacher who refused to answer questions concerning his membership in the Communist Party violated his fourteenth amendment right to due process).

34. See Lerner v. Casey, 357 U.S. 468 (1958) (upholding dismissal of subway conductor employed by city transit authority who refused to answer questions concerning membership in Communist Party); Beilan v. Board of Pub. Educ., 357 U.S. 399 (1958) (upholding dismissal of public school teacher who refused to answer questions relating to affiliations with the Communist Party); Garner v. Board of Pub. Works, 341 U.S. 716 (1951) (affirming constitutional validity of a city's loyalty oath).

35. Note, supra note 16 , at $411-12$.

36. 374 U.S. 398 (1963). 
"It is too late in the day to doubt that the liberties of religion and expression may be infringed by the denial of or placing conditions upon a benefit or privilege." 37

Gradually, during the 1950s and 1960s, a new doctrine evolved in stark contrast to the right-privilege distinction of the prior decade. Reasoning that the state should not be able to accomplish unconstitutional ends through indirect ineans, ${ }^{38}$ the Court developed the unconstitutional conditions doctrine which prohibited government from conditioning employment upon the surrender of constitutional rights. ${ }^{39}$

The court articulated the unconstitutional conditions doctrine in Keyishian v. Board of Regents, ${ }^{40}$ in which the Court declared unconstitutional the New York statute upheld in Adler. Justice Brennan, speaking for the Court, stated: "[C]onstitutional doctrine which has emerged since [Adler] has rejected its niajor premise. That premise was that public employment ... may be conditioned upon the surrender of constitutional rights which could not be abridged by direct government action." in Keyishian reflects the Court's shift from an emphasis on the state's imterest in efficiency to one on the interest of public employees $\mathrm{n} 1$ securing their right to freedom of association." 42

\section{The Pickering Test}

In 1968, the Court's analysis noved further away from its initial posture of favoring the governnent in public employment cases involving constitutional claims. In Pickering v. Board of Education, ${ }^{43}$ the Court introduced a new standard for determining whether a negative personnel decision violated a public employee's right to free speech: "The problem in any case is to arrive at a balance between the interests of the teacher, as a citizen, in commenting upon matters of public concern and the interest of the State, as an enployer, in promoting the efficiency of the public services it perforins through its einployees." 44

In Pickering, a high school teacher was fired for writing a letter to a newspaper. The letter criticized the school board's allocation of funds between educational and athletic programs and the board's nethods of informing the taxpayers of the need for additional revenues. The Court held that the letter clearly involved matters of public interest first,

\footnotetext{
37. Id. at 404.

38. Van Alstyne, supra note 23, at 1445-46.

39. Note, supra note 28 , at 1744.

40. 385 U.S. 589 (1967).

41. Id. at 605.

42. Note, supra note 28 , at $1740-41$.

43. 391 U.S. 563 (1968).

44. Id. at 568 .
} 
because it stated an opinion regarding the "preferable inanner of operating the school system,"45 and second, because the letter raised questions upon which "free and open debate is vital to informed decision-making by the electorate." 46 Pickering suggests that any speech by a public employee which concerns the "preferable manner of operating" a government mstitution or which is "vital to informed decision-making" falls within the parameters of the public concern requirement and is constitutionally protected.

Subsequent decisions interpreted the Pickering Court's emphasis on the right of a public employee "as a citizen, in commenting on matters of public concern" to mean that, as a threshold matter, the public employee's speech must have been about a matter of public concern in order to be granted constitutional protection. ${ }^{47}$ If, and only if, the court finds that the employee's speech was of public concern, will it then balance the interests of the government employer against the interests of the public einployee. ${ }^{48}$

Public employee speecl cases in the 1970s failed to clarify what, in the Court's opinion, constituted a matter of public concern. In $M t$. Healthy City School District Board of Education v. Doyle, ${ }^{49}$ the Court uncritically accepted the district court's finding that a teacher's telephone call to a radio station disclosing tlie scliool's dress code for teachers was constitutionally protected speech without discussing the public concern requirement at any lengtl1. ${ }^{50}$ Similarly, in Givhan v. Western Line Consolidated School District, ${ }^{51}$ the Court did not discuss the public concern requirement when it lield that a public employee's speech during a private conversation with lier employer was constitutionally protected even though it was not addressed to the public.52

In the 1980s, the Court began efforts to shape the parameters of the public concern requirement. These efforts, lowever, have produced con-

45. Id. at 571 .

46. Id. at 571-72.

47. If the public employee's expression "cannot be fairly characterized as constituting speech on a matter of public concern, it is unnecessary for us to scrutinize the reasons for her discliarge." Connick v. Myers, 461 U.S. 138, 146 (1983).

48. See, e.g., Rankin v. McPlierson, 107 S. Ct. 2891, $2896-97$ (1987) (tlireshold question in applying balancing test is whether employee's speecl may be fairly characterized as speech of public concern); Connick, 461 U.S. at 146 (if speech cannot be fairly characterized as speech of public concern, the court need not review further).

49. 429 U.S. 274 (1977).

50. Id. at 284 (holding that if the employer can prove by a preponderance of the evidence that it would liave reached the same personnel decision absent the employee's protected expression, the court will upliold the employer's personnel decision).

51. 439 U.S. 410 (1979).

52. Id. (holding that protected expression does not lose its protection simply because it takes place in a conversation between a public employee and his/her supervisor). 
flicting signals. In Connick v. Myers, ${ }^{53}$ a 1983 decision, the Court seemed to narrow the definition of public concern by finding that a public employee's criticisin of a government office's operation was not of public concern. Four years later, in Rankin v. McPherson, ${ }^{54}$ the Court seemed to broaden the definition, concluding that a statement of personal opinion about the President of the United States, speech neither about the "preferential manner of operating" a government institution nor "vital to informed decision-making" by the electorate, was nevertheless of public concern. These different results are examined below.

\section{Connick v. Myers}

In Connick v. Myers, an assistant district attorney was discharged for distributing a questionnaire to her officemates. ${ }^{55}$ Sheila Myers had been employed as an assistant district attorney for five and one-half years. In 1980, Myers was informed that she was to be transferred to a different section of the criminal court, a transfer she strongly opposed. Following notification of her transfer, Myers prepared a questionnaire concerning office transfer policy, office morale, the need for a grievance cominittee, and whether employees felt pressured to work in political campaigns. Myers was fired after she distributed this questionnaire to fifteen other assistant district attorneys.

The district court lield that the questionnaire involved matters of public concern since the issues it presented related "to the effective functioning of the District Attorney's Office." ${ }^{56}$ The Fifth Circuit Court of Appeals affirmed the district court's opinion. ${ }^{57}$ The Supreme Court, however, reversed, holding that all but one question on Myers' questionnaire were not of public concern since they did not aid the public in "evaluating the performance of the District Attorney as an elected official" nor seek to "bring to light actual or potential wrongdoing or breach of public trust" by the district attorney. ${ }^{58}$ The sole question that the Court found to be of public concern related to whether employees felt pressured to work on pohtical campaigns.

On the one hand, it appears that the Connick Court made it more difficult for a public employee to prove that his speeclı was of public concern by imposing two additional criteria-assisting in the of public evaluation of elected officials and disclosing breaches of public trust. On

53. 461 U.S. 138 (1983).

54. 107 S. Ct. 2891 (1987).

55. Connick, 461 U.S. at 142.

56. Myers v. Connick, 507 F. Supp. 752,758 (E.D. La.), aff'd without opinion, 654 F.2d 719 (5th Cir. 1981), rev'd, 461 U.S. 138 (1983).

57. Myers v. Connick, 654 F.2d 719 (5th Cir. 1981) (decided without published opinion), rev'd, 461 U.S. 138 (1983).

58. Connick v. Myers, 461 U.S. 138, 148 (1983). 
the other hand, the Connick Court stated, "Whether an employee's speech addresses a matter of public concern must be determined by the content, form, and context of a given statement, as revealed by the whole record." In this respect, it appears that the Connick Court gave lower courts a greater degree of discretion in deciding whether to grant first amendment protection to public employee speech. A court could now take into account criteria other than content when determining whether the speech was of public concern, such as the loosely defined "form and context" of the employee's statement.

Myers' questionnaire should have met the Pickering public concern requirement since it concerned the operation of a government office and arguably contained information necessary for "informed' decisionmaking" by the electorate. ${ }^{60} \mathrm{~A}$ questionnaire reveahing low office morale and disclosing that assistant district attorneys do not have confidence in their supervisors would be helpful to the public in deciding whether to reelect the district attorney. Specifically, the public might vote against a district attorney who could not command employees' trust and confidence.

Nevertheless, the Connick Court found only one question, relating to political campaigns, of public concern. The Connick Court explicitly excluded speech about the internal workings of an office from first amendment protection, ${ }^{61}$ despite Pickering's finding that speech that contributes to self-government, political and social change, or informed decisionmaking by the electorate fulfills the public concern requirement. ${ }^{62}$ Even though criticism of the operation of a government office seems essential to self-government, such speech might not meet the threshold inquiry under the Connick Court's construction of the public concern requirement.

Two elements appear to underlie the Connick Court's denial of constitutional protection to speech concerning the operation of a government office. First, the Connick Court feared that a broad definition of public concern would turn every employee grievance into a constitutional case against the government. The Court explained:

To presume that all matters which transpire within a government office are of public concern would mean that virtually every remark-and certainly every criticism directed at a public official-would plant the seed of a constitutional case. While as a matter of good judgment, public officials should be receptive to constructive criticism offered by their employees, the First Amendment does not require a public office to be

\footnotetext{
59. Id. at $147-48$.

60. See supra notes $45-46$ and accompanying text.

61. Connick, 461 U.S. at 154.

62. Id. at 145.
} 
run as a roundtable for employee complaints over internal office affairs. ${ }^{63}$

Recognizing the government employer's need for flexibility in making personnel decisions, the Court excluded employee grievances concerning internal office pohicy from the parameters of pubhic concern. ${ }^{64}$

Second, it appears that the Court wanted to find a way to give greater weight to the government's interests in certain public employee cases. As one commentator has noted, the Connick Court estabhished different standards of review depending on the degree to which the speech could be characterized as "of public concern."65 If the speech "cannot be fairly considered as relating to any matter of political, social, or other concern to the community," the court will completely defer to the government employer's personnel decision. ${ }^{66}$ If the speech is of " $\mathrm{lim}$ ited" pubhic concern, a "wide degree of deference to the employer's judgment is appropriate."67 Only if the speech is "substantially" or "inherently" of public concern will the court apply the Pickering balance without great deference to the state as employer. ${ }^{68}$

Since it found only one of Myers' questions to be of pubhic concern, the Court could give greater weight to the government's contention that distribution of the questionnaire disrupted close working relations in the office. In so doing, however, the Court held that speech addressing issues that might normally be considered vital to informed public decisionmaking-that is, the questions about office morale, office policy, and employee confidence in superiors-were not of public concern.

The Connick Court purported to deal with the public concern requirement by discussing the Court's historical concern with protecting the right of all citizens, public employees included, to participate in public affairs, ${ }^{69}$ but did not fairly apply the standards set forth in Pickering in determining whether Myers' speech was of public concern. The Court inerely cited several cases to demonstrate that "speech on public issues occupies the " "highest rung of the heirarchy [sic] of First Amendment values."," 70 Despite its extensive discussion of the importance of

63. Id. at 149 .

64. Id. at 154 .

65. Lieberwitz, Freedom of Speech in Public Sector Employment: The Deconstitutionalization of the Public Sector Workplace, 19 U.C. DAvis L. REv. 597, 642-46 (1986).

66. Connick, 461 U.S. at 146; see also Lieberwitz, supra note 65, at 643 (speech on private matters, as opposed to matters of public concern, receives rational basis review).

67. Connick, 461 U.S. at 152; see also Lieberwitz, supra note 65, at 643-44 (speech of limited public concern, like speech on private matters, also accorded a low level standard of first amendment review).

68. Connick, 461 U.S. at 148 n.8, 152; see also Lieberwitz, supra note 65, at 645-46 (stronger showing by government may be necessary if employee's speech is substantially or inherently of public concern).

69. Connick, 461 U.S. at 144-45.

70. Id. at 145 (quoting NAACP v. Claiborne Hardware Co., 458 U.S. 886, 913 (1982) (quoting Carey v. Brown, 447 U.S. 455, 467 (1980))). 
speech on matters of public concern, the Connick Court did not adequately explain why Myers' questions were not matters of public import, even though they related to the effective functioning of the district attorney's office and thus appeared to meet the public concern standards set forth in Pickering. ${ }^{71}$

\section{Rankin v. McPherson}

In Rankin v. McPherson, ${ }^{72}$ a clerical employee in a county constable's office was discharged for making a statement about the President of the United States. McPherson was working in a room inaccessible to the public when she heard a radio news bulletin detailing an assassination attempt on President Reagan. McPherson and a coworker began discussing Reagan's policies and McPherson stated, "[I]f they go for him again, I hope they get him."73

The district court entered summary judgment in favor of the constable and county, finding that McPherson's speech was "private speech," and thus failed to meet the public concern threshold for first amendment protection. ${ }^{74}$ The Fifth Circuit Court of Appeals reversed, finding that "the life and death of the President are obviously matters of public concern."75 The Supreme Court, in a 5-4 decision, agreed with the Fifth Circuit, holding that the statement "plainly dealt with a matter of public concern" since it was "made in the course of a conversation addressing the policies of the President's administration" and "came on the heels of a news bulletin regarding . . . an attempt on the life of the President."76

The Rankin Court could conclude that McPherson's statement was speech of public concern only because it viewed the statement in the context of the prior discussion of the President's policies and the news bulletin announcement. ${ }^{77}$ Expression that amounts to a personal opinion is not necessarily vital to informed decisionmaking by the electorate nor essential to self-government. ${ }^{78}$ Thus, if McPherson's statement had been made without a prior discussion of the President's policies, the Court might not have been able to justify calling the speech of public concern. In such a case, it would have been irrelevant that McPherson's statement was made during a private conversation in a manner unlikely to disrupt

71. Speech concerning government behavior, policy, or personnel is ordinarily considered political speech even by those who urge a narrow interpretation of first amendment protections. See, e.g., Bork, Neutral Principles and Some First Amendment Problems, 47 IND. L.J. 1, 27-28 (1971).

72. 107 S. Ct. 2891 (1987).

73. Id. at 2895 .

74. McPherson v. Rankin, 786 F.2d 1233, 1235 (5th Cir. 1986), aff'd, 107 S. Ct. 2891 (1987).

75. Id. at 1236 .

76. Rankin, 107 S. Ct. at $2897-98$.

77. Id.

78. For a discussion of the "newsworthiness" interpretation of the public concern requirement, see infra note 114 and accompanying text. 
the workplace. Under the Pickering test, once the speecli fails the public concern requirement, the court may not inquire into otler factors surrounding the discharge. ${ }^{79}$

Rankin and Connick suggest that tlie Court can broaden or narrow the parameters of the public concern requirement as it sees fit. Because the public concern requirement plays sucli a central role in determining the constitutional status of the public employee's speech, the rationale belind the requirement slrould be scrutinized in order to reveal the Court's underlying concerns in creatimg a threshold inquiry.

\section{II}

\section{A Closer look at the Public Concern Requirement}

It is not immediately apparent why the Court requires public employee speecli to be of public concern as an initial hurdle. The Court could just as siniply balance the employee's interest in free speech against the employer's interest in managing the workplace. Balancing would satisfy the Court's concern with protecting the constitutional rights of government employees through judicial review of adverse government personnel decisions involvimg speech claims while protecting the government's interest in effective operation.

By requiring the public employee to show that his speecli was of public concern, the Supreme Court has demonstrated a disproportionate concern for the government einployer's interest in managing the workplace. If the public employee cannot demonstrate that the speecli "relat[es] to any matter of pohtical, social, or other concern to the community," the deciding court must grant government officials "wide latitude in managing their offices, without intrusive oversight by the judiciary in the name of the First Amendment." ${ }^{80}$ This threshold, however, may be overbroad and thus fail to protect constitutionally speech that does not affect the government's ability to exercise its managerial function.

\section{A. Concerns Underlying The Threshold Inquiry}

The threshold test was created to address the government employer's interest in managerial authority. This authority can be impaired in two ways. The employee's speech nnay have a disruptive impact on the workplace, and judicial review of the government's disci-

79. [W] hen a public employee speaks not as a citizen upon matters of public concern, but instead as an employee upon matters only of personal interest, . . . a federal court is not the appropriate forum in which to review the wisdom of a personnel decision taken by a public agency allegedly in reaction to the employee's behavior.

Connick v. Myers, 461 U.S. 138, 147 (1983).

80. Id. at 146. 
plinary action may impair the government employer's managerial authority.

\section{Disruptive Impact of Speech On The Workplace}

Public employee speech may impair the government institution's ability to function. Imagine the chaos that would reign if public employees felt the first amendment protected the right to speak out of turn in meetings, to misrepresent the agency's position to the public, or to wander around the office speaking incessantly to coworkers trying to do their jobs. The Supreme Court apparently established the threshold test to remove such clear cases of disruptive speech from judicial review.

The Court has traditionally recoginzed the government employer's need to control public einployee speech, especially when such speech impairs the government institution's ability to carry out its legitimate objectives. $^{81}$ The Court rationalizes this need for control in the following way:

[T]he Government, as an employer, must have wide discretion and control over the management of its personnel and internal affairs. This includes the prerogative to remove employees whose conduct hinders efficient operation and to do so with dispatch. Prolonged retention of a disruptive or otherwise unsatisfactory employee can adversely affect discipline and morale in the workplace, foster disharmony, and ultimately impair the efficiency of an office or agency. ${ }^{82}$

In Connick v. Myers, ${ }^{83}$ for example, the Court upheld the employee's disinissal because her speech seemed to have interfered with "the efficient and successful operation of the District Attorney's office." 84 The Court stressed that Myers used office tine and space to prepare and distribute her questionnaire, ${ }^{85}$ and that "the manner of distribution required not only Myers to leave her work but others to do the same in order that the questionnaire be completed." 86 The Court also noted that the employer felt 'Myers' questionnaire was an act of insubordination which interfered with working relationships" between enployees and supervisors. ${ }^{87}$

While recognizing the government's need for managerial discretion, the Court has accorded constitutional protection to public employee speech that was not disruptive of the workplace. In Pickering v. Board of

81. Post, Between Governance and Management: The History and Theory of the Public Forum, 34 UCLA L. REV. 1713, 1767-75 (1987).

82. Connick, 461 U.S. at 151 (quoting Arnett v. Kennedy, 416 U.S. 134, 168 (1974) (Powell, J., concurring in part and concurring in the result in part)).

83. 461 U.S. 138 (1983).

84. Id. at 151 (quoting Myers v. Connick, 507 F. Supp. 752, 759 (E.D. La. 1981)).

85. Id. at 153 .

86. Id.

87. Id. at 151 . 
Education, ${ }^{88}$ for example, the teacher did not use classroom time to express his views to his students nor did he direct his statements "towards any person with whom [he] would normally be in contact in the course of his daily work as a teacher." 89 He simply wrote a letter to a newspaper. The Pickering Court carefully noted that the relationships between the teacher and the school board were "not the kind of close working relationships for which it can persuasively be claimed that personal loyalty and confidence are necessary to their proper functioning."90 Because the teacher's speech in Pickering did not disrupt the school's ability to educate, the Court granted first amendment protection to the speech and found the teacher's discharge unconstitutional.

Sinilarly, in Rankin v. McPherson, ${ }^{91} \mathrm{McPherson's} \mathrm{comments} \mathrm{to} \mathrm{her}$ coworker did not impair the office's abihty to function. McPherson did not criticize anyone in the office, nor did she challenge her superiors. She made her remarks in a conversation with one coworker. Even though another employee overheard the conversation and was disturbed by McPherson's views, the Court found the speech insufficiently disruptive of the workplace to justify McPherson's dismissal. ${ }^{92}$

Pickering, Connick, and Rankin illustrate that one of the Supreme Court's reasons for creating a threshold test was to deny constitutional protection to public employee speech which has a disruptive impact on the workplace. A second reason was to prevent impairment of governmental managerial authority caused by judicial review of governınent disciplinary actions.

\section{Disruptive Impact of Judicial Review}

Judicial review of government personnel decisions, or even the possibility of judicial review, may impair the government employer's ability to manage the office. ${ }^{93}$ Impairment might take the form of overly cautious personnel decisions, such as the retention of outspoken but incompetent employees. Government already suffers from the image of retaining incompetent employees. ${ }^{94}$ Judicial review of government personnel actions could further weaken a government employer's manage-

\footnotetext{
88. 391 U.S. 563 (1968).

89. Id. at 569-70.

90. Id. at 570 .

91. 107 S. Ct. 2891 (1987).

92. Id. at 2899 .

93. The Court has never stated explicitly that the purpose of the Pickering threshold inquiry is to prevent the potentially adverse impact of judicial review on the government's managerial authority.

94. Frug, Does the Constitution Prevent the Discharge of Civil Service Employees?, 124 U. PA. L. REv. 942, 945 (1976).
} 
rial authority by increasing the costs of acting decisively. ${ }^{95}$ If a governinent manager does not know whether an adverse personnel decision will result in costly hitigation, she may hesitate before firing an employee for speech-related activity. ${ }^{96}$

Although judicial review may have a dainaging effect on a government employer's ability to exercise managerial authority, the Court should not resort to the extreme of refusing to review all government personnel actions. Even though "ordinary dismissals from government service . . . are not subject to judicial review even if the reasons for the dismissal are alleged to be mistaken or unreasonable,"97 coinplete refusal to review public employee speech cases would be tantamount to rejection of the unconstitutional conditions doctrine, which prohibits conditioning government employment on the surrender of constitutional rights. ${ }^{98}$ Thus, while it may not be desirable for the courts to review every negative government personnel decision contested on first ainendinent grounds, at least some judicial review is necessary to ensure that the government does not arbitrarily disnniss einployees for exercising their constitutional rights.

The Supreme Court devised the public concern threshold inquiry to avoid disruption of government's functions through either einployee speech or judicial review of government personnel decisions. The current threshold inquiry is poorly suited to this goal, however, for reasons discussed below.

\section{B. Problems with the Public Concern Threshold}

\section{Focus on Public Concern is Inappropriate}

If the Supreme Court consistently recognized the importance of speech on public issues, it would review regulations of public employee speech on matters of public concern with the same strict scrutiny it accords such speech in other contexts. In most first amendinent cases, if the speech in question is of public concern, the Court tends to accord the speech added protection; ${ }^{99}$ some Justices have even urged that the Court grant such speech absolute protection. ${ }^{100}$ For example, in New York

95. Professor Robert Post argues that judicial second-guessing of managerial decisions about speech can completely undermine managerial authority. Post, supra note 81, at 1771-72.

96. However, given the importance granted to the first amendment and the unique position government employees hold with respect to information not generally available to the public, it is legitimate to require that government employers be circumspect in dismissing employees for speechrelated activity. See infra notes $130-35$ and accompanying text.

97. Connick v. Myers, 461 U.S. 138, 146-47 (1983).

98. See supra notes $30-42$ and accompanying text.

99. See, e.g., Dun \& Bradstreet, Inc. v. Greenmoss Builders, 472 U.S. 749, 759 (1985) (speeial concern for speech on public issues; less concern for speech on matters of private concern).

100. See, e.g., Wieman v. Updegraff, 344 U.S. 183, 193-94 (1952) (Black, J., concurring) 
Times Co. v. Sullivan, ${ }^{101}$ the Court noted that "freedom of expression upon public questions is secured by the First Amendment," and that "debate on public issues should be uninhibited, robust, and wideopen." 102 In Bridges v. California, ${ }^{103}$ the Court stated, "[I]t is a prized American privilege to speak one's mind, altlougl not always with perfect good taste, on all public institutions." 104

In the public employee speecli context, lowever, if the speech is of public concern, the Court balances-a process which some commentators criticize as less protective than normal first amendment scrutiny of nongovernment speech. ${ }^{105}$ This inconsistent treatment may be justified by the special nature of the public workplace setting and judicial concern for inanagerial and workplace efficiency, as is suggested by the language in Connick, Pickering, and Rankin. ${ }^{106}$ The public concern requirement, however, does not directly address this problem because it focuses on the nature of the speech in question rather than on whether the speech interfered with workplace efficiency. Formulating the threshold inquiry in a way that prevents judicial consideration of the actual disruptive impact of the employee's speech, thus runs contrary to the Supreme Court's objectives.

Simce the public concern requirement is a threshold inquiry, failure to meet this requirement precludes the court's inquiry into other relevant questions, such as whether the speech actually impaired close working relations between the employee and his supervisor, whether the speecl1 demonstrated that the employee was unfit to perform his duties, and whether the speech actually disrupted the smooth operation of the workplace. Since concern for the government's ability to manage the workplace underlies the threshold inquiry, these are key questions which the court should examine before it demes protection to a public employee's speech rights.

The current public concern test, however, allows the court to con-

(arguing that the right to speak on matters of public concern must be wholly free, undiluted, and unequivocal).

101. 376 U.S. 254 (1964).

102. Id. at 269-70.

103. 314 U.S. 252 (1941).

104. Id. at 270 (footnote omitted).

105. See, e.g., Schauer, Categories and the First Amendment: A Play in Three Acts, 34 VAND. L. REV. 265, 303-04 (1981) (arguing that while balancing has traditionally been associated with less first amendment protection, this does not necessarily have to be the case); see also Emerson, Toward a General Theory of the First Amendment, 72 YALE L.J. 877, 912-14 (1963) (criticizing ad hoc balancing); Frantz, Is The First Amendment Law? - A Reply to Professor Mendelson, 51 CaLIF. L. REV. 729, 746-49 (1963) (arguing that courts can manipulate the balance to achieve whatever result desired); Note, Nonpartisan Speech in the Police Department: The Aftermath of Pickering, 7 HAstings CONST. L.Q. 1001, 1018 (1980)(authored by Kevin William Finck) (arguing that the Pickering balancing test has produced inconsistent results in lower courts).

106. See supra text accompanying notes $83-92$. 
sider disruption only after the initial threshold of the Pickering test has been crossed. Since the Supreme Court created the threshold inquiry to deny constitutional protection to speech disruptive of the workplace and to reduce the disruptive impact of judicial review, the threshold test should focus on these concerns.

\section{Scope of Public Concern is Unclear}

The Supreme Court's definition of public concern in public employee speech cases differs from its definition in other contexts ${ }^{107}$ and even differs among public employee cases. ${ }^{108}$ As a result, the scope of public concern is unclear and appears susceptible to manipulation.

Specifically, in some situations, the Court has narrowed the definition to exclude speech normally considered of public concern. For example, speech concerning the way an agent of the government does his job usually would be construed as being of public concern. ${ }^{109}$ Speech about any aspect of governmental affairs is also generally considered a matter of public concern. ${ }^{110}$ The Connick Court, however, made it clear that an employee grievance over internal office matters did not meet its definition of public concern in the public employee speech context. ${ }^{111}$ Public employee speech concerning "internal office affairs" is considered speech of purely private concern. ${ }^{112}$

Conversely, the Court has broadened the definition to include speech that does not fit the Court's current definitions of public concern. For example, in Rankin v. McPherson, ${ }^{113}$ the Court found an expression of purely personal opinion a matter of public concern. Viewed in isolation, McPherson's statement, "if they go for him again, I hope they get him," is not speech on a social or political issue "vital to informed decision-making" by the electorate. It is questionable whether the average person on the street would care to know a government employee's personal view of the President. It is unlikely that the public would find such a statement newsworthy. What is newsworthy is the fact that the government fired the employee for her statement, not the statement itself. ${ }^{114}$

107. See infra notes 109-12 and accompanying text.

108. See infra notes 113-14 and accompanying text.

109. Rosenblatt v. Baer, 383 U.S. 75, 94 (1966) (Black, J., concurring and dissenting).

110. First Nat'l Bank of Boston v. Bellotti, 435 U.S. 765, 776-77 (1978); Mills v. Alabama, 384 U.S. 214, 218 (1966).

111. Connick v. Myers, 461 U.S. 138, 154 (1983).

112. Id. Even the Fourth Circuit, which has interpreted the public concern requircment quite broadly, has recognized that private personnel grievances are not of public concern. See, e.g., Berger v. Battaglia, 779 F.2d 992, 998 (4th Cir. 1985), cert. denied, 106 S. Ct. 2278 (1986).

113. 107 S. Ct. 2891 (1987).

114. There has been much debate over whether the newsworthiness of an item should be a measuring stick of public concern. Compare Note, supra note 14, at 307 (arguing that if a newspaper thinks a matter is newsworthy, then it is "of public concern" as well) with Cover, The Supreme Court 
While the Rankin Court purported to apply the public concern test, it seems more likely that the Court actually considered the disruptive impact of the employee's speech first, then decided the speech should be protected.

Rankin and Connick illustrate the problems that an unclear standard may cause. Admittedly, creating well-defined standards in the area of public employee speech is no easy matter. Justice Marshall, writing for the majority in Pickering, explicitly endorsed the lack of a precise standard in employee discharge cases: "[W]e do not deem it either appropriate or feasible to lay down a general standard against which all such statements may be judged." 115 The Court furtler acknowledged that rigid rules cannot accommodate the "enormous variety of fact situations in which critical statements by . . . public employees may be thought by their superiors . . . to furnish grounds for dismissal." 116 Such guidelines, however, would enable managers to predict, with some degree of certainty, the hitigation effects of their adverse personnel decisions. ${ }^{117}$

Varying the scope of the public concern requirement in the public employee context frustrates the very purpose of the threshold test. Because the public concern test is defined inconsistently, the test actually exacerbates the effects of judicial review on managerial authority. The Court can dissipate the disruption of judicial review eitler by deferring entirely to government officials' judgement on when employee speech disrupts the institution, or by creating clear and consistent standards for government employers to follow. The public concern requirement that the Court currently apphies neither allows for complete deference nor provides clear and consistent standards.

The foregoing discussion illustrates that the public concern requirement fails in two significant respects. First, in focusing on the nature of the speech rather than on the speech's disruption of the workplace, the public concern requirement fails to address directly the problem of government's ability to effectively exercise managerial authority in the public workplace. If the public employee's speech is not of public concern, the court never reaches the balancing test in which it could consider whether the speech was actually disruptive. Second, inconsistent application of

1982 Term-Foreword: Nomos and Narrative, 97 HARV. L. REv. 4, 172 n.65 (1983) (arguing that a "headline test" of public concern would "undermine the first amendment's historic neutrality with respect to the impact of expression").

115. Pickering v. Board of Educ., 391 U.S. 563, 569 (1968).

116. Id.

117. On the other hand, rigid rules may hamper needed managerial discretion. Government managers sometimes must exercise their authority in unique and unforeseeable situations. Strict rules are unsuitable "where the action to be controlled is non-recurring' and in situations involving 'personalized, individual application.' ' Post, supra note 81, at 1818-19 (quoting Jowell, The Legal Control of Administrative Discretion, 1973 PUB. L. 178, 202). 
the public concern requirement exacerbates the potentially disruptive impact of judicial review on the government's ability to manage the workplace effectively. Since the decision whether to review a public employee speech case should turn on both the disruptive impact of the speech itself and the perceived need for the government employer to manage the workplace free from judicial oversight, ${ }^{18}$ the Court should reformulate the threshold inquiry to better address these concerns.

\section{III}

\section{A THEORETICAL FraMEWORK FOR UNDERSTANDING Judicial Review of Public EMPLOYeE SPEECH}

This Section offers a theoretical framework for understanding how courts have decided public employee speech cases. It first discusses the judiciary's considerations in determining whether the speech is constitutionally protected. It then discusses two different levels of judicial review: independent review and deference.

\section{A. Determining Whether the Speech is Constitutionally Protected}

\section{The Management-Governance Distinction}

Determining whether a public employer has properly discharged an employee for engaging in speech requires balancing the interests of the government employer in managing the workplace against the free speech interests of the employee. ${ }^{119}$ In his writings on the first amendment, Professor Robert Post characterizes these interests in terms of the distinction between two types of state authority, management and governance. ${ }^{120}$

Management principles generally apply when the state controls the speech of individuals performing functions within its own institutions. The state, in its role as an employer, has an interest in controlling employee speech that prevents the organization from attaining its goals. A government employer umilaterally specifies the organization's values and goals. ${ }^{121}$ In order for an institution to function smoothly, the employees must accept the basic goals established by the employer without question. ${ }^{122}$ Accordingly, when managerial authority is at issue, normal first amendment rules may be relaxed to give the government

118. Professor Robert Post argues that in the context of public forum doctrine, the Court's decision not to review a case turus not on the nature of the speech, but rather on the relationship between judicial review and the nature of the managerial authority at issue. The question which the Court should ask, according to Post, is whether judicial review would impair the goverument's ability to attain its legitimate objectives. Post, supra note 81 , at 1770-72.

119. Pickering v. Board of Educ., 391 U.S. 563, 568 (1968).

120. Post, supra note 81 , at 1775 .

121. Id.

122. Id. 
employer room to attain its legitimate objectives. ${ }^{123}$

Governance principles are implicated when the state controls the speech of its citizens. In such cases, the state is subjected to the usual restrictions of the first amendment. ${ }^{124}$ In its capacity as government, the state may not unilaterally determine values and command their acceptance because citizens, not the state, determine common values through public discussion and debate. ${ }^{125}$ Enforcement of first amendment principles ensures that such discussion is not suppressed unreasonably.

It is tempting to view the distimction between governance and management as simply a line between state control of speech inside and outside a government institution. If such were the case, however, all public employee speech would implicate solely managerial rather than governance concerns and would not be protectible under the first amendment. Professor Post explains that drawing lines at the workplace door oversimplifies the concepts of management and governance. According to Post, "the distinction between management and governance turns on the priority accorded to proposed objectives." 126 If government action is viewed as an exercise of managerial authority, then government-determined goals and values are given unquestioned priority. If government action is seen as a matter of governance, then the government's goals and values are open to question and debate. ${ }^{127}$

When it is clear that purely managerial interests are involved, the employee's speech should not receive first amendment protection. ${ }^{128}$ Purely managerial imterests may arise when a public employee's speech clearly disrupts the workplace. The relationship between a government employer and its employees, however, ceases to be managerial when the interest of the government employer im controlling its employees' speech is "not significantly greater than its interest in limiting a similar contribution by any member of the general public." 129 In this situation, where the state is interfering with the employee's role as a citizen, the public employee's speech should receive first amendment protection.

\section{Public Employees As a Valuable Source of Information}

Although there is a strong argument that speech that relates to the einployment is likely to be disruptive, not all such public employee speech slould be suppressed. Public employee speech that is critical of the government employer, although threatening to management, may be

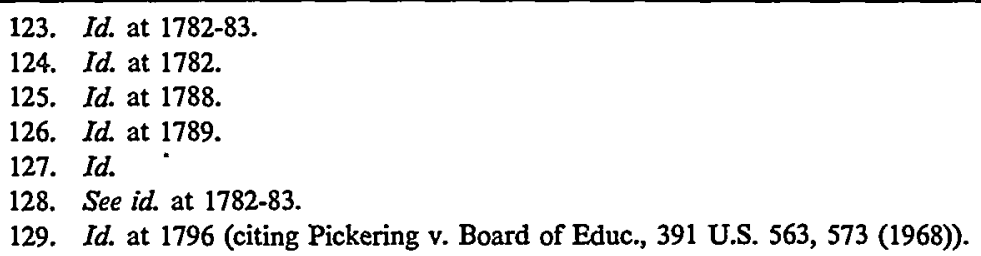


useful to the general public. Disclosure of an employer's wrongdoing or breach of the public trust is therefore protected speech. ${ }^{130}$ First amendment protection, however, should not be limited to speech that exposes illegalities. ${ }^{131}$ Disclosure of questionable, though legal, government conduct can also be useful to society.

For example, in Lewis v. Harrison School District No. $1^{132}$ the Eighth Circuit held that a high school principal's criticism of the superintendent was protected speech. Lewis was the principal of a high school. His wife was a teacher at the same school, and had made some complaints to the superintendent. In response, the superintendent told Lewis to "inuzzle" his wife, ${ }^{133}$ and notified Lewis' wife that she would be transferred to another school. At a public school board meeting to discuss the proposed transfer, Lewis spoke against his wife's transfer and criticized the superintendent for lack of professionalism. The school board subsequently discharged Lewis for having publicly expressed his dissatisfaction with the superintendent.

The Eighth Circuit found that Lewis' speech was of public concern, noting a large turnout at the school board meeting, a local newspaper article about the meeting, and a petition signed by several teachers supporting the Lewises. ${ }^{134}$ Even though Lewis' speech involved a personnel dispute, the court considered it important enough to merit first amendment protection. His criticism of the superintendent's lack of professionalism was constitutionally protected even though the speech did not expose a breach of trust or an illegal act, because the speech disclosed information which was useful to the public and to which only an employee within the school system would have had access. ${ }^{135}$

\section{Low Threshold Preferred}

The Supreme Court's public employee speech decisions indicate that the Court hesitates to deny first anendment protection to public employee speech. ${ }^{136}$ For example, in Pickering v. Board of Education, ${ }^{137}$

130. See, e.g., Connick v. Myers, 461 U.S. 138, 148 (implying that such speech is of public concern).

131. See supra note 58 and accompanying text.

132. 805 F.2d 310 (8th Cir. 1986), cert. denied, 107 S. Ct. 2481 (1987).

133. Id. at 312 .

134. Id. at 314 .

135. Post, The Management of Speech: Discretion and Rights, 1984 SuP. CT. REv. 169, 198 (discussing the value of employee information for the democratic supervision of government institutions).

136. The Court's insistence on a low-threshold test may stem from its repudiation of the rightprivilege distinction. Under the right-privilege regime, government could fire its employees even if a dismissal infringed on the employee's constitutional rights, and the courts could not intervene. See supra notes 19-29 and accompanying text. The gradual acceptance of the notion that a government employer could not condition employment on the surrender of constitutional rights enabled courts to 
Mt. Healthy City School District Board of Education v. Doyle, ${ }^{138}$ and Rankin v. McPherson, ${ }^{139}$ the Court found that the employees' speech met the threshold public concern inquiry and therefore was constitutionally protected. Even in the one public employee speech case in which the Supreme Court upheld the government's adverse personnel decision, Connick v. Myers, ${ }^{140}$ the Court refused to completely deny first amendment protection to the public employee's speech. After a long discussion of how most of Myers' speech was not of public concern, the Connick Court stated that '[ $[b]$ ecause one of the questions in Myers' survey touched upon a matter of public concern and contributed to her discharge, we must determine whether Connick was justified in discharging Myers." 141 Although the Court ultimately held that Myers' discharge "did not offend the First Amendment,"142 it refused to abdicate coinpletely its power of review. These decisions indicate that the current public concern inquiry is a low threshold test and that most public employee speech receives constitutional protection.

The Fourth Circuit has recognized the Supreme Court's insistence on a low threshold test. In Berger v. Battaglia, ${ }^{143}$ the court held that a police officer's entertainment speech was of public concern. A police officer who performed impersonations of Al Jolson in blackface while offduty was ordered by his departinent to cease such performances. The police department had received numerous complaints from black citizens who objected to the white officer's impersonations of the famous black singer, and feared that relations with the black community would be undermined if the officer contmued his performances. In holding that the police officer's speech was protected by the first amendment, the court stated:

Pickering, its antecedents, and its progeny-particularly Connick-make it plain that the "public concern" or "community interest" inquiry is better designed - and more concerned - to identify a narrow spectrum of employee speech that is not entitled even to qualified protection than it is to set outer limits on all that is. The principle that emerges is that all public employee speech that by content is within the general protection of the first amendment is entitled to at least qualified protection against public employer chilling action except that which, realistically viewed, is

review government personnel actions which infringed on employees' constitutional rights. See supra notes $30-42$ and accompanying text.

137. 391 U.S. $563,570-72(1968)$.

138. 429 U.S. 274, 284 (1977) (accepting district court's finding that teacher's speech was protected by first amendment).

139. 107 S. Ct. 2891, 2898 (1987).

140. 461 U.S. 138 (1983).

141. Id. at 149 . :

142. Id. at 154.

143. 779 F.2d 992 (4th Cir. 1985). 
of purely "personal concern" to the employee-most typically, a private personnel grievance. ${ }^{144}$

In view of the Supreme Court's apparent resistance to a high threshold test, most public employee speech is protected under the first amendment. This, however, does not mean that all employee disciplinary actions are reversed. The granting of first amendment protection is just the first step in the court's process of reviewing a government employer's disciplinary action based on employee speech activity. Next, the court must decide whether the government employer's action was constitutionally permissible.

\section{B. Judicial Review of Constitutionally Protected Speech}

\section{Independent Review and Deference}

Once the public employee's speech is deemed constitutionally protected, the court must determine whether the government employer's interest im managing the workplace outweighs the employee's interest in free expression. ${ }^{145}$ The court can resolve this question either by reviewing the record independently or by leaving this determination to the government employer's judginent. ${ }^{146}$ When the court independently reviews a government personnel decision, it carefully examines the record to determine whether the employee's speech interfered with the government institution's operations and to ensure that the government has not disregarded the employee's constitutional rights. ${ }^{147}$

Alternatively, the court can defer to the government employer's decision that the employee's expression was disruptive and therefore legitimately suppressed. Under a deference approach, the judiciary retains some control over the government employer's management of employee speech. Courts set the legal standards which government managers must try to follow, but government employers are given wide latitude to determine when these standards are met. ${ }^{148}$

144. Id. at 998.

145. Post, supra note 81, at 1783.

146. Id. Professor Post argues that deference is justified when the institution requires insulation from judicial review. He suggests a three-pronged test for deciding when the court should defer to institutional authority. First, the government officials must have understood the principles of the first amendment and tried in good faith to implement them. Second, judicial review must lead to contamination of the organization, destruction of organizational culture, and loss of needed flexibility. Third, the potential damage to institutional authority by independent judicial review of its decisions must outweigh the damage to the employee's need to maintain fidelity to external roles. Id. at $1810-12$.

147. See Post, supra note 135, at 213-14.

148. Cf. id. at 216 (a deference approach in the context of appellate review of trial court judgments means that the appellate court retains the ability to review the outcome of a particular decision and to ensure that the lower court considered the appropriate factors). 


\section{Considerations Underlying the Choice of Level of Review}

The arguments for deference can be summarized in terms of judicial economy, judicial competency, and impairment of managerial authority. One objective of the judicial system is judicial economy or the securing of the "just, speedy, and inexpensive determination of every action."149 One might argue that obligating courts to independently review every public employee speech case would bog down the judicial process and defeat the goals of the judicial system. ${ }^{150}$

This argument, however, is overbroad, as it apphes to almost any instance that involves issues susceptible to judicial review. Every lawsuit which is filed crowds the judicial system's already overloaded dockets. Moreover, regardless of the marginal added burden, the importance of the constitutional guarantee of free speech should outweigh admimistrative concerns of judicial efficiency.

A inore persuasive argument in favor of deference is that a government manager is better able to evaluate the disruptive effect an employee's speech might have on the workplace. Because the governinent manager has direct contact with the workplace, she may be in a better position to gauge the effect of the employee's speech on coworkers and superiors. ${ }^{151}$ There are two responses to this argument. First, a government manager is more likely than a neutral third party to decide that an employee's speech impairs managerial authority because the manager has a personal interest in suppressing adverse or unflattering employee speech. The court, on the other hand, is less susceptible to bias as an independent, outside observer. If the court, rather than the government employer, decides whether the employee's speech disrupted the workplace, the reasons for the disciplinary action can be scrutinized carefully to ensure that the employee's speech was legitimately suppressed. In addition, a government employer's personnel decision may be the result of extraneous concerns, such as personality conflict, rather than actual disruption of the workplace. Given the lack of external controls on the government manager's decision and the institutional bias inherent in an employer-employee dispute, the court is more competent than the government employer to decide whether the discharge was justified.

Second, although courts may justifiably defer to bodies that are better equipped to make certain determinations, there is no significant

149. Celotex Corp. v. Catrett, 106 S. Ct. 2548, 2555 (1986) (quoting FED. R. Civ. P. 1).

150. Friendly discusses a similar problem in the context of appellate review of lower court decisions. "[T]here is a limit on the capacity of the judicial system to entertain appeals and afford retrials." Friendly, Indiscretion About Discretion, 31 EMORY L.J. 747, 761 (1982).

151. The argument that government managers are more competent than the courts to decide when speech impairs their managerial authority is similar to the argument that trial courts are more competent than appellate courts to determine the facts since the trial court is in direct contact with the witnesses. See id. at 759 . 
advantage in letting a government employer, rather than a court, determine whether an employee's speech can legitimately be suppressed under first amendment principles. The decision to discipline a public employee for speech-related activity may be made by individuals who disagree with, or are unaware of, first amendment principles. Moreover, even if the decisionmakers are aware of the relevant legal issues, records of their decisions might fail to disclose whether they gave these issues proper consideration. Courts are certainly more expert than government administrators in weighing first amendment considerations. Alleged lack of judicial competency therefore should not bar independent review since the government manager is not necessarily better able than the court to determine whether the public employee's first amendment rights were legitimately abridged.

The strongest argument in favor of deference is that judicial review of government personnel actions can impair the managerial authority structure upon which the government institution rests. ${ }^{152}$ Judicial review of employee disinissals inight lead to overly cautious personnel decisions, exacerbating the problem of retaining incompetent einployees. ${ }^{153}$ Managerial discretion is especially important when problems are nonrecurring or highly personalized, as is frequently the case with einployer-employee relations. ${ }^{154}$ It was precisely because of the diversity of situations in whicl public employee speecli disputes iniglit arise that the Pickering Court refused to lay down a general standard for such speech. ${ }^{155}$

The potential for undermining a governinent employer's managerial authority is a persuasive reason to defer to the employer's judgment in public employee speech cases instead of independently reviewing the personnel decision. Indeed, this is probably the main reason why courts have been reluctant to review public einployee speech cases in general. Nonetheless, free expression and specifically public einployee speech, are so valuable to society that courts should ensure their protection through review of governinent personnel decisions. A government employer might otherwise use its authority over its einployees to infiuence public debate, or to keep valuable information froin reaching the public.

Independent judicial review also ensures that each case reaches a just result. ${ }^{156}$ When a court defers to the judgment of government officials that a public employee's speech disrupted the workplace, it risks relying on a judgment that miglit be colored by the government official's

152. See Post, supra note 81 , at 1777 (suggesting that the Court's primary concern in non-public forum cases has been the protection of managerial authority).

153. See supra notes $93-96$ and accompanying text.

154. See Post, supra note 135, at 223-24.

155. Pickering v. Board of Educ., 391 U.S. 563, 569 (1968).

156. Post, supra note 135, at 229 (discussing appellate review of restraining orders). 
interest in managing a workplace free of interference. Judicial review of the government employer's personnel decisions can correct bias or errors in judgment. ${ }^{157}$

Additionally, judicial review of public employee speecl ensures consistent results. Deference to the judgment of individual government officials is problematic because similar types of employee speech may be treated differently by different employers. By reviewing adverse personnel decisions, courts can estabhish clear principles of law through the process of case-by-case adjudication. ${ }^{158}$ The establishment of clear standards ensures imcreased certainty and consistency for government employers faced with personnel decisions involving employee speech issues. Government officials can, over time, learn what types of speech are constitutionally protected, and will be better able to predict litigation outcomes when making personnel decisions. ${ }^{159}$

\section{IV}

\section{Reformulation of the PICKERING Test}

This Section presents a reformulation of the Pickering test. It is not intended as an alternative to the Pickering test, but rather it reveals low courts actually understand and apply Pickering.

Under the current construction of the Pickering test, the public concern inquiry serves two functions: It determines whether constitutional protection attaches to the speech at all, and it determines the level of judicial review of constitutionally protected speech. ${ }^{160}$ These functions, however, should be handled separately. Since the Supreme Court's primary concerns are the disruptive impact of the employee's speech on the workplace and the impairment of government managerial authority caused by judicial review, the threshold test should reflect these concerns rather than focusing on the nature of the speech. A second inquiry is needed because the decision to defer or review turns on inore than just the nature or the content of the speecl. By separating the issue of constitutional protection from the issue of the level of judicial review, the proposed reformulation can better accomplish the objectives underlying Pickering and inore clearly articulate the reasons wliy courts defer or review.

The reformulation suggests that as a threshold inatter, the court determines whether a public einployee's speech, on its face, clearly

157. Id.

158. Id.

159. Thus, institutional authority will be less impaired over time. See supra notes $93-96$ and accompanying text.

160. See supra text accompanying notes 47 and $65-68$. 
impairs a government institution's ability to function. ${ }^{161}$ If it is clear from a mere presentation of the facts of the case, without further investigation or review, that the speech significantly disrupts the workplace environment, the court upholds the government employer's adverse personnel decision without reviewing the reasons for the discharge. The court grants first amendment protection to all other public employee speech.

The reformulation then requires the court to engage in a second inquiry before reaching the second prong of the Pickering test, where it balances the employee's interest in free speech against the government's interest in managing the workplace. Once the court finds the speech constitutionally protected, it must decide what role the public employee assumed at the time of the speech in question. If the employee spoke in his capacity as a citizen, the court independently reviews the record. In its independent review, the court balances actual or potential workplace disruption against the importance of protecting a public employee's expression of ideas. If, on the other hand, the employee spoke in his capacity as an employee, the court defers to the government employer's decision that the speech actually or potentially interfered with the efficient operation of the workplace. Deferring, in essence, allows the government employer, in place of the court, to conduct the balancing test, and thus tips that balance in favor of the government's interests.

\section{A. The New Threshold Inquiry: Clear Impairment of the Government Institution's Ability to Function}

The newly articulated threshold inquiry is whether the employee's speech, on its face, clearly impairs the government agency's ability to function. ${ }^{162}$ Impairment is found whenever the employee's speech makes it impossible for the government institution to carry out its duties or accomplish its legitimate objectives. In these clear cases, the court must give government employers complete discretion to determine the appropriate response to such speech by denying constitutional protection to the employee's speech.

For example, the disclosure of military secrets or speech affecting national security would not receive constitutional protection under the

161. While the public concern requirement will no longer be the threshold inquiry, the nature of the speech can be considered as a factor in determining the role of the employee. See infra text accompanying notes 183-90.

162. The new threshold test closely parallels the test set forth in Tinker v. Des Moines Independent Community School District, 393 U.S. 503 (1969). In Tinker, the Court held that where the state could not demonstrate that the student expression in question would "'materially and substantially interfere with the requirements of appropriate discipline in the operation of the school," " the student expression was constitutionally protected and could not be prohibited. Id. at 509 (quoting Burnside v. Byars, 363 F.2d 744, 749 (5th Cir. 1966)). 
reformulated threshold test because such speech clearly impairs the ability of the defense department to function. Similarly, if an employee is told to present Position $A$ at a meeting, but wants to present Position $B$, the reformulated threshold test would deny that employee's first amendment claim because an institution's ability to function depends on the wilhingness of employees to follow their supervisors' instructions. ${ }^{163}$ The speech of an Internal Revenue Service employee who tells the public to protest government expenditures on defense by not paying taxes would not receive constitutional protection because such speech directly and significantly interferes with the Internal Revenue Service's ability to collect taxes. ${ }^{164}$

Under the reformulated threshold test, constitutional protection is denied ouly when the employee's speech is clearly disruptive. In such cases, government employers are given complete discretion to control employee speech because purely managerial interests are concerned. However, when it is not completely clear that the employee's speech disrupted the workplace, both managerial and governance issues may be involved, and the public employee's speech is granted constitutional protection. The court then either reviews the disciplimary action ${ }^{165}$ or defers to the government employer's judgment that the speech was disruptive. ${ }^{166}$

This reformulation of the threshold test shifts the burden of proof from the employee to the einployer. Under the current Pickering test, a public employee must demonstrate that his speech was of public concern before the speech is accorded first amendment protection. ${ }^{167}$ Under the reformulated threshold test, the government employer has the burden of proving that the speech clearly impaired the ability of the government institution to function before the speech is denied first amendment protection. Shifting the burden of proof is appropriate since the state has punished the exercise of free speech. ${ }^{168}$ Since protection of the first amendment is critical to democratic government, the state should have to show that a suppression of speech is justified by overriding considerations.

The reformulated threshold test, like the current threshold test, is purposely low, granting constitutional protection to most public

163. See Post, supra note 81 , at 1771-72.

164. Under the current threshold test, the court would probably reach the same conclusions, although ostensibly for different reasons. Since the current threshold test focuses on the nature or content of the speech, the court would need to find that the speech did not address a matter of public concern before denying constitutional protection.

165. See, e.g., Rankin v. McPherson, 107 S. Ct. 2891 (1987).

166. See, e.g. Connick v. Myers, 461 U.S. 138 (1983).

167. See supra text accompanying note 80 .

168. Tinker v. Des Moines Indep. Community School Dist., 393 U.S. 503, 509 (1969). 
employee speech. ${ }^{169}$ Unlike the current public concern test, however, the reformulated threshold inquiry directly addresses the Supreme Court's underlying concerns by focusing on the disruptive impact of the speech on the workplace.

Additionally, the new threshold test is less ambiguous than the public concern inquiry. This added clarity could lead to more uniform application of the threshold inquiry by lower courts, enabling government employers to predict with more certainty whether employee speech is constitutionally protected. Consequently, the reformulated threshold test reduces the disruptive impact of judicial review on government's managerial authority.

Finally, the reformulated threshold test differs from the current public concern requirement because it does not allow the court to use the threshold determination as a means of deciding the appropriate level of judicial review. ${ }^{170}$ The clear impairment test's sole function is to determine whether the employee's speech is constitutionally protected.

\section{B. The Employee/Citizen Distinction: Password To Balancing}

Once an employee's speech has passed the threshold test, the court determines whether the speech actually interfered with the operation of the workplace. The court can either make this determination on its own, or it can defer to the government employer's judgment that the speech was disruptive. ${ }^{171}$ The reformulation requires the court to engage in a second inquiry at this point; one which focuses on the role of the employee at the time the speech occurred. In this inquiry, the court determines whether the employee spoke as an employee or as a citizen.

Currently, if a government employee appears to have spoken in his capacity as an employee, the court defers to the judgment of the employer in suppressing the speech. On the other hand, if it appears that the public employee spoke in his capacity as a citizen, the court independently reviews the discharge decision by balancing the competing interests of the government employer and employee. The reformulation does not add anything new to the Pickering test; it merely requires the court to explain its decision to defer or review in terms of the employee/citizen distinction. Three factors seem particularly relevant to the determination whether the employee has acted as a citizen or as an employee: First, whether the speech took place within the office or outside in the public realm; second, whether the speech was related to the employment; and third, whether the speech was of public concern.

169. See text accompanying notes $136-42$.

170. See text accompanying notes $65-68$.

171. Post, supra note 81, at 1783. 


\section{Did the Speech Occur Within the Government Institution?}

The first factor the court must consider in making the employee/ citizen distmction is whether the speech in question took place within the government office. Speech that takes place outside a government institution generally interferes less with the operations of the institution than speech which occurs within the workplace. In addition, government suppression of employee speech outside the workplace may raise concerns that the government is attempting to influence public debate or impair public access to information. These considerations weigh in favor of independent review. On the other hand, the government may have strong managerial interests in regulating employee speech which occurs on the job because such speech may prevent the institution from functioning efficiently. These considerations weigh in favor of deference.

When applying the current Pickering test, the Supreme Court has never exphicitly stated that the place where the speech occurs is relevant to the level of judicial review. Nevertheless, the Court's public einployee speech decisions indicate that this is, in fact, one consideration. In Pickering v. Board of Education, ${ }^{172}$ for example, a public high school teacher sent a letter to a newspaper criticizing the school administration. The teacher did not express his views in the classroom or anywhere else on the high school campus. Since the teacher's speech neither "impeded [his] proper performance of his daily duties in the classroom" nor "interfered with the regular operation of the schools generally," the Court concluded that "the interest of the school administration in limiting teachers' opportunities to contribute to public debate is not significantly greater than its interest in limiting a similar contribution by any meniber of the general public." 173 Because the teacher spoke in his capacity as a citizen when he sent his letter to the newspaper, the Court refused to defer to the school adninistration's determination that the speech adversely affected its ability to inanage the school.

Connick v. Myers ${ }^{174}$ similarly denionstrates that the place where the speech occurred is relevant to the court's decision to review or defer. In Connick, the Court deferred to the government employer's judgment that Myers' questionnaire was an act of insubordination which caused a miminsurrection in the office, ${ }^{175}$ noting that the questionnaire was prepared and distributed at the office, and required Myers and her coworkers to leave their work. ${ }^{176}$ "[T] ering], exercised her rights to speech at the office supports [the govern-

172. 391 U.S. 563 (1968).

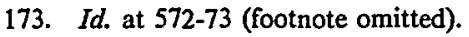

174. 461 U.S. 138 (1983).

175. Id. at 151-52.

176. Id. at 153 . 
ment employer's] fears that the functioning of his office was endangered." 177

In contrast, the Court chose not to defer to the government employer's judgment in Rankin v. McPherson, ${ }^{178}$ a case in which the discharged employee's speech also took place withm the office. In his concurrence, Justice Powell explained why the Court did not defer to the government employer's decision that the employee's casual remark regarding the presidential assassination attempt was disruptive: "The risk that a single, offhand comment directed to only one other worker will lower morale, disrupt the work force, or otherwise undermine the mission of the office borders on the fanciful."179

Rankin illustrates that the place of expression is only one factor the court currently considers when deciding whether to defer to the government employer or independently review the disciplinary action. The court may retain its power to review the personnel decision even if the speech arose within the workplace environment. Other factors in the employee/citizen distinction may contribute to the decision to review rather than defer.

\section{Was the Speech Employment-Related?}

A second factor im the employee/citizen distinction concerns the relationship between the speech and the employment. Since speech unrelated to the worker's employment is generally unlikely to threaten workplace efficiency, government efforts to suppress such speech are less likely to reflect purely managerial considerations and are more likely to implicate governance concerns. Thus, when the public employee's speech is not related to the job, the court leans towards reviewing the government's disciplinary action.

This factor may explain why the Rankin Court did not defer to the government employer's judgment that the employee's speech was disruptive. In Rankin v. McPherson, ${ }^{180}$ the employee's expression amounted to a personal opinion of the President. The employee was not employed by the Secret Service whose function is to protect the President, nor was she employed by the Executive Branch of the federal government. She worked in a county constable's office. Therefore, her views on the assassination attempt did not raise questions about her capacity to perform her job. Since Rankin's speech was more like expression of a citizen than expression of an employee, the Court independently scrutinized the rea-

177. Id.

178. 107 S. Ct. 2891 (1987).

179. Id. at 2901 (Powell, J., concurring).

180. 107 S. Ct. 2891 (1987). 
sons for the discharge and held that this public employee's discharge was improper.

Conversely, when the public employee's speech is related to the job, the court is more likely to defer than review. For instance, in Connick $v$. Myers, ${ }^{181}$ the employee's criticism of the district attorney's office policies and practices was related to her employment. The Court consequently deferred to the government employer's judgment that the speech was significantly disruptive.

Whether the employee's speech related to the job, in and of itself, is not determinative of the court's decision to defer or review. A court is not required to defer to the government employer's judgment merely because the employee's speech related to the employment. In Pickering v. Board of Education, ${ }^{182}$ for example, the employee's criticism of the school administration's methods of distributimg revenue related to his employment, yet the Court independently reviewed the discharge decision and balanced the employee's interests against those of the governinent.

\section{Was the Speech Of Public Concern?}

Under the proposed reformulation, the nature of the speech is no longer the crucial threshold issue that determines whether the speech is constitutionally protected. Nevertheless, it still may contribute to the court's decision to defer or review. Independent review of speech on matters of public concern is generally appropriate because in such situations the employee is more likely to be speaking as a citizen than as an einployee.

For example, in Pickering v. Board of Education, ${ }^{183}$ the Court noted that the teacher's speech concerning the allocation of school funds touched on matters "of public record on which lis position as a teacher in the district did not qualify him to speak with any greater authority than any otlier taxpayer." 184 Since tlie interest of the school administration in suppressing the teacher's speech was "not significantly greater than its interest in limiting a similar contribution by any member of the general public," the Court found that the school liad encroached on the teacher's role as a citizen in speaking out on matters of public concern and reversed the teaclier's discliarge. ${ }^{185}$

181. 461 U.S. 138, 154 (1983)(employee's questionnaire characterized as an employee grievance concerning internal office policy).

182. 391 U.S. $563,572-73$ (1968)(teacher's letter criticizing the Board which employed him).

183. 391 U.S. 563 (1968).

184. Id. at 572 .

185. Id. at 573 . 
In contrast, in Connick v. Myers, ${ }^{186}$ the Court found that the employee's speech was of only "limited" public concern and was for the most part an employee grievance. Accordingly, the Court deferred to the government employer's judgment that the speech was disruptive. ${ }^{187}$

Pickering and Connick indicate that if the employee's speech is of public concern, the Court is more likely to independently review the government's personnel decision. If, on the other hand, the employee's speech is not of public concern or is of "limited" public concern, then the court is more likely to view the speech as an employee grievance. In such cases, since the employee was speaking more in her capacity as an employee than as a citizen, the Court will defer to the government employer's judgment that the speech impaired the government's managerial authority.

In determiming whether a public employee's speech constitutes a matter of public concern, courts should construe the meaning of public concern liberally. ${ }^{188}$ Speech which is vital to informed decisionmaking and speech concerning the operations of government should be found of public concern. ${ }^{189}$ Similarly, speech which aids the public in evaluating the performance of elected public officials or which discloses "actual or potential wrongdomg or breach of public trust" 190 by public officials should be deemed a matter of public concern.

\section{The Employee/Citizen Distinction and the Court's Public Employee Speech Decisions}

As the recent Supreme Court public employee speech cases demonstrate, all three factors will rarely support the same conclusion. In Pickering v. Board of Education, ${ }^{191}$ for example, the teacher's criticism of the school administration was held to be of public concern and took place outside the school institution, but the speech related to the employment. Nonetheless, the Court independently reviewed the record and reversed the teacher's dismissal. The fact that the teacher's speech concerned an issue of concern to the local community and was expressed in a forum that allowed the public to hear his message were the considerations that persuaded the Court to review the discharge rather than defer.

In Rankin v. McPherson, ${ }^{192}$ the employee made a comment at work

186. 461 U.S. 138 (1983).

187. See supra text accompanying notes $65-68$ and 175 .

188. For example, speech concerning a government official's performance of her job or any other aspect of governmental affairs should be considered of public concern. See supra text accompanying notes 109-10.

189. See supra text accompanying notes $45-46$.

190. Connick v. Myers, 461 U.S. 138, 148 (1983).

191. 391 U.S. 563 (1968).

192. 107 S. Ct. 2891 (1987). 
about the assassination attempt on President Reagan. The Court found that the employee's speech was of public concern. Even though the speech occurred at the workplace, the Court independently reviewed the employee's discharge, because the speech was not employment-related and was of public concern.

In Mt. Healthy Board of Education v. Doyle, ${ }^{193}$ the teacher's statements about the school's dress code made outside the school institution also were found to be of public concern, but the speech was related to the employment. In Givhan v. Western Line Consolidated School District, ${ }^{194}$ the teacher's speech, alleging racially discriminatory practices by the school, was of public concern, but took place on the job and was employment-related. Although the Court never addressed the question of whether to review or defer, these two cases illustrate that rarely will all three factors support eitler deference or review in a particular case.

Perhaps the strongest example of a case in which all three factors support one result is Connick v. Myers. ${ }^{195}$ In Connick, the Court held that the questionnaire Myers distributed was of only "limited" public concern. Additionally, Myers' speech was employment-related and took place during working hours at the workplace. Because these factors indicated that Myers spoke in her capacity as an employee, the Court deferred to the government employer's judgment that the speech interfered with close working relations in the office.

\section{Recommendation: Review Whenever One Factor Indicates Employee Spoke as a Citizen}

If the speech is clearly of public concern, is unrelated to employinent, and occurred outside of work, the case for independent review is strongest because in such cases the employee has spoken as a citizen; when the state attempts to control the speech of its citizens, governance concerns require judicial review. If the speech is not of public concern, but is related to the employment and took place at work, the case for deference is strongest because the employee, in his role as an employee, threatens the government's ability to manage the workplace effectively. As discussed above, in most cases all three factors do not clearly support either deference or independent review.

Recent Supreme Court decisions suggest that the Court has adopted a "totahty of the circumstances" approach to deciding whether to defer or review. If, on the whole, it appears that the employee was speaking more in her role as a citizen than an employee, the Court reviews the government's action. If the factors indicate that the employee spoke

193. 429 U.S. 274 (1977).

194. 439 U.S. 410 (1979).

195. 461 U.S. 138 (1983). 
more as an employee than as a citizen, the Court defers. Under the reformulation, the Court could continue to use a "totality of the circumstances" approach. Such an approach, however, is not the most appropriate method of determming whether a public employee's free speech mterests have been legitimately abridged. Instead, this Comment suggests that the courts should independently review any case in which one of the factors indicate that the employee spoke as a citizen.

In Connick v. Myers, ${ }^{196}$ the Court upheld a government decision to discharge an assistant district attorney merely because she circulated a questioimaire around the office. Under a "totality of the circumstances" approach, the Court's decision to defer to the government employer was the appropriate choice. The speech related to the employment and took place on the job. Furthermore, the speech was found to be of only "limited" public concern. On the whole, the factors indicated that the employee spoke more as an employee than as a citizen.

However, the Connick Court's decision to defer to the government employer was inconsistent with first amendment principles. The employee's speech criticized the operation of a government office and concerned inatters useful to the public in deciding whether to reelect the District Attorney. Therefore, the speech was of public concern. ${ }^{197}$ This fact sliould have been sufficient reason for the Court to review the employer's decision because of the importance historically accorded speecl1 of public concern. ${ }^{198}$ In New York Times Co. v. Sullivan, ${ }^{199}$ the Supreme Court acknowledged the importance of speech on public issues as a means of ensuring that government is responsive to the will of the people:

'The maintenance of the opportunity for free political discussion to the end that government may be responsive to the will of the people and that changes may be obtained by lawful means ... is a fundamental principle of our constitutional system.' ... '[I]t is a prized American privilege to speak one's nind, although not always with perfect good taste, on all public institutions. 200

Because of the importance of free expression, and especially the need to protect public employees from being fired for expressing legitimate and important views, courts should independently review all public employee speech cases that implicate governance interests. If any single

196. Id.

197. See supra text accompanying notes $188-90$.

198. See supra text accompanying notes 99-104. Even if only the single question concerning political campaigns qualified as a matter of public concern, the importance of such speech should justify independent review.

199. 376 U.S. 254 (1964).

200. Id. at 269 (quoting Stromberg v. California, 283 U.S. 359, 369 (1931) and Bridges V. California, 314 U.S. 252, 270 (1941)). 
factor supports a finding that the einployee spoke as a citizen, courts should not defer to the government employer.

The decision to review does not mean that the court will ultimately reverse the government einployer's action. Review merely allows the court, and not the employer, to balance the government employee's interest in free speech against the government employer's interest in managing the workplace.

\section{VI \\ CONCLUSION}

In the area of speech in the public workplace, the Supreme Court has acknowledged two competing interests: the public einployee's interest in exercising her first amendment right to free speech and the government employer's interest in managing the workplace. The Supreme Court created a two-prong test to meet these concerns. The threshold public concern test was intended to address the government einployer's managerial interest, and the balancing test to meet the employee's free speech concerns. By focusing solely on the nature of the speech at issue, however, the current public concern threshold test does not directly address the interest in preventing workplace disruption and impairment of managerial authority.

The threshold inquiry should turn on whether disruption was caused by either the speech itself or judicial review. Under the proposed reformulation, if a review of the facts reveals that the public employee's speech clearly inpaired the government's inanagerial authority, the speech is denied first amendment protection. Otherwise, the speech is constitutionally protected.

The reformulation requires courts to engage in a second inquiry before reaching the balancing test. This inquiry focuses on the role of the employee, and asks: (1) whether the speech took place at the workplace; (2) whether the speech was related to the employinent; and (3) whether the speech was of public concern. Current Supreme Court decisions suggest that the Court apphes a "totality of circuinstances" approach in deciding whether to review or defer. If the facts indicate that the employee spoke inore in her capacity as an employee than as a citizen, then the court defers to the government employer's judgement that the speech was disruptive. If the einployee spoke more as a citizen than as an employee, the court independently reviews the personnel decision to determine whether the free speech interests of the public einployee outweigh the government einployer's interest in workplace efficiency. This Comment, however, suggests that whenever any single factor supports a finding that the einployee spoke as a citizen, courts should independently review the government disciplinary action. 
This reformulation of the Pickering test more accurately reflects the Supreme Court's policy objectives in public employee speech cases. Moreover, this reformulation advances the Court's objectives by recognizing the importance of review in public employee cases. The requirement of review whenever one factor of public concern exists will deter government employers from chilling important commentary from public employees, depriving the public at large of useful information, and undermining the freedom of speech. 